\title{
MODERN MORPHOLOGICAL DIAGNOSTICS OF ULCERATIVE COLITIS AND IRRITABLE BOWEL SYNDROME: HISTOLOGICAL, HISTOCHEMICAL AND IMMUNOHISTOCHEMICAL CRITERIA
}

DOI: 10.36740/WLek202103101

\author{
Pavlo P. Snisarevskyi \\ SHUPYK NATIONAL HEALTHCARE UNIVERSITY OF UKRAINE, KYIV, UKRAINE
}

\begin{abstract}
The aim is to establish diagnostic and differential-diagnostic criteria for UC and IBS based on a complex morphological (histological, histochemical, immunohistochemical) study. Materials and methods: In this study, it was used autopsy and biopsy material - fragments of the mucous membrane of the large intestine. The material was divided into 5 groups. The first group ( $G 1$ included autopsy material from 6 cases, in which, during autopsies and microscopic examination, we found no general pathological processes in the gastrointestinal tract. The second group $(G)$ included biopsy material from 34 patients with diagnosed UC of the $1^{\text {st }}$ activity degree. The third group (G 3 ) included the biopsy material of 27 patients with UC of the $2^{\text {nd }}$ degree of activity. The fourth group $(G 4)$ included biopsy material from 19 patients, diagnosed with UC of the $3^{\text {rd }}$ degrees of activity. The fifth group (G5) included biopsy material from 82 patients with clinically diagnosed IBS. Histological, histochemical, immunohistochemical, statistical research methods were used. Results: There are characteristic morphological changes in the mucous membrane of the large intestine in UC of varying degrees of activity, such as changes in the architectonics of crypts of varying severity; presence of erosive and ulcerative defects. Inflammatory and desquamative-dystrophic changes take place in the epithelial layer adjacent to erosive and ulcerative defects. The number of goblet cells of crypts decreases and the size of vacuoles in goblet cells reduces. The intensity of mucin secretion contained in the vacuoles of the goblet cells lowers; there is a partial or complete loss of pericryptal myofibroblasts; the proliferative potential of the intestinal crypts epithelium activates.

Conclusions: Differential diagnostic criteria, revealed by the author, improve the morphological diagnosis of UC and IBS, optimizing the tactics of managing patients with this colorectal pathology.
\end{abstract}

KEY WORDS: ulcerative colitis, irritable bowel syndrome, morphological differential-diagnostic criteria

Wiad Lek. 2021;74(3 p.I):381-387

\section{INTRODUCTION}

The number of people diagnosed with diseases of the gastrointestinal tract is increasing every year all over the world [1]. $\mathrm{UC}$ in terms of prevalence is significantly inferior to other gastroenterological diseases. However, due to severity of the course, frequency of complications and mortality, it is a leader in the structure of diseases of the gastrointestinal tract [2].

The endoscopic method of research (colonoscopy) plays a decisive role in UC diagnosis [3]. Despite its effectiveness and diagnostic accuracy in identifying intestinal pathology, colonoscopy has a number of disadvantages (invasiveness, risk of complications, pain and discomfort) [4]. Often during a colonoscopy, we take a targeted biopsy from various parts of the large intestine, followed by its examination by a pathologist [5].

In UC, colonobioptate examination has not only diagnostic, but also prognostic value [6]. The morphological diagnosis of UC sometimes causes certain difficulties even for the most experienced pathologists. Despite the available arsenal of modern morphological research methods, certain diagnostic difficulties also arise in the differential diagnosis of UC with various pathological conditions including IBS.
Differential diagnosis of UC and IBS is difficult due to the common clinical manifestations, pathophysiological mechanisms, etc. The existing diagnostic difficulties have caused disagreements among scientists regarding the relationship between UC and IBS. Most scientists believe that UC and IBS are different pathological conditions of the large intestine. Some scientists defend the concept of recognizing UC and IBS as different forms of the same disease. There is also a high incidence of UC against the background of IBS, frequent persistence of IBS-like symptoms after achieving remission of UC, possible «superimposing» of one disease on the course of another [7].

All of the above actualizes the need for a continuous search for morphological criteria that would allow accurate and correct UC and IBS diagnostics, including a differential one.

\section{THE AIM}

The aim is to establish diagnostic and differential-diagnostic criteria for UC and IBS based on a complex morphological (histological, histochemical, immunohistochemical) study. 


\section{MATERIALS AND METHODS}

In this study, we used autopsy and biopsy material - fragments of the mucous membrane of the large intestine. The material was divided into 5 groups. G 1 included autopsy material from 6 cases, in which, during autopsies and microscopic examination, we found no general pathological processes in the gastrointestinal tract. G 2 included biopsy material from 34 patients with diagnosed UC of the $1^{\text {st }}$ activity degree. G 3 included the biopsy material of 27 patients with UC of the $2^{\text {nd }}$ degree of activity. G 4 included biopsy material from 19 patients, diagnosed with UC of the $3^{\text {rd }}$ degrees of activity. G 5 included biopsy material from 82 patients with clinically diagnosed IBS. In patients of groups 2-4, UC was diagnosed based on clinical data, results of colonoscopy, and colonobioptates examination.

The resulting material, fixed in a $10 \%$ solution of neutral formalin ( $\mathrm{pH}$ 7.4) for 24-48 hours, was treated according to the generally accepted technique and embedded in paraffin. From paraffin blocks on a rotary microtome HM 325 (Thermo Scientific, USA), serial sections with a thickness of 2-3 $\mu \mathrm{m}$ were made, stained with hematoxylin and eosin. To determine the morpho-functional state of the goblet cells, we performed the PAS reaction.

Immunohistochemical study was performed using rabbit monoclonal antibodies (MCA) to Ki-67 (clone SP6) and murine MCA to alpha-smooth muscle actin (clone 1A4). An Ultra Vision Quanto HRP detection system was used for visualization. The MCA and the imaging system were manufactured by Thermo Fisher Scientific (USA).

Microscopic examination and photoarchiving were performed using light optical microscope Axio Imager. A2 (Carl Zeiss, Germany) with data processing system with magnified lenses $\times 5, \times 10, \times 20, \times 40$, binocular nozzle 1.5 and glasses 10 with ERc 5 s camera, light optical microscope Primo Star (Carl Zeiss, Germany) with AxioCam 105 camera.

The obtained digital data were processed, using the program Statistica 10.0. Central trends in the groups were compared on averages, using the nonparametric Mann-Whitney U test. Differences were considered significant at $\mathrm{p}<0.05$, taking into account the Bonferroni correction [8].

\section{RESULTS AND DISCUSSION}

In $G$, while studying microspecimens stained with hematoxylin and eosin, it was found focal desquamative changes in the epithelium of the colon mucosa in 1 case $(16.7 \%)$. The revealed desquamation of the epithelial layer is due, from our point of view, to its artifactual change, occurring during the histological processing of the material.

Observational microscopy of the slides in G 2 in the epithelium of the mucous membrane of the colon in all cases revealed moderate inflammatory, degenerative and desquamative changes. In 29 cases $(85.3 \%)$ they were combined with formation of multiple superficial erosions, the depth of which reached the surface parts of the lamina propria of the mucous membrane (fig. 1).
In $\mathrm{G} 3$, in 22 cases (81.5\%), we found multiple erosions in the mucous membrane, superficial in places, deep in some of the visual fields. Deep erosions led to defects that spread to the entire thickness of the lamina propria of the mucous membrane. In 5 cases (18.5\%), erosive and ulcerative changes were detected in the mucous membrane. The depth of the ulcers reached the muscle plate of the mucous membrane or the submucosa (fig. 2). It was determined pronounced inflammatory, dystrophic and desquamative changes at the edges and at some distance from the erosive and ulcerative defects in the epithelium of the mucous membrane in all cases.

Observational microscopy in G 4 in the mucous membrane showed erosive changes in 10 cases $(52.6 \%)$, erosive and ulcerative in 9 cases (47.4\%). In the epithelial layer, which was adjacent to these defects, in all cases, pronounced inflammatory and desquamative-dystrophic changes were determined.

Thus, with UC of varying degrees of activity, characteristic morphological changes in the mucous membrane of the colon are erosive and ulcerative defects, as well as inflammatory and desquamative-dystrophic changes in the epithelial layer. Other scientists have also noted similar morpho-functional changes [9].

In the study, it was also revealed an increase in erosive-ulcerative, inflammatory, desquamative-dystrophic changes from $G 2$ to $G 4$ in the epithelial layer of the colon mucosa.

In UC, the processes of apoptosis and necrosis are the leading in the formation of erosive and ulcerative defects in the mucous membrane of the large intestine. Scientists have shown an increase in the processes of apoptosis as the course of UC increases with the subsequent dominance of necroinflammatory changes in colonocytes [10].

In all cases in G 5, it was revealed moderate inflammatory and degenerative changes in the epithelial layer in the mucous membrane of the colon. In 20 cases (24.4\%), a combination of inflammatory, dystrophic and desquamative changes was found in the epithelium of the mucous membrane (fig. 3).

Comparing the results, obtained in G 2-5, we noted that in IBS compared with UC of varying degrees of activity in the mucous membrane of the colon, firstly, erosive and ulcerative changes were not detected; secondly, in all cases less pronounced inflammatory and dystrophic changes were found in the epithelium, which in some cases were combined with desquamative changes.

Complex epithelial barrier of the colon, as is known, allows you to maintain tolerance to commensal microflora and food agents, effectively protecting the body from pathogens [11]. Damage of the epithelial barrier, revealed in the study in the wall of the large intestine in IBS and $\mathrm{UC}$, upsets this balance and leads to the development of inflammation.

The first barrier of the large intestine, protecting the internal medium of the body from bacteria and damaging factors, is the mucus, produced by the goblet cells. As we know, goblet exocrinocytes are abundant in crypts. The mucus, produced by these cells, prevents the adhesion and invasion of microorganisms, not interfering with the 


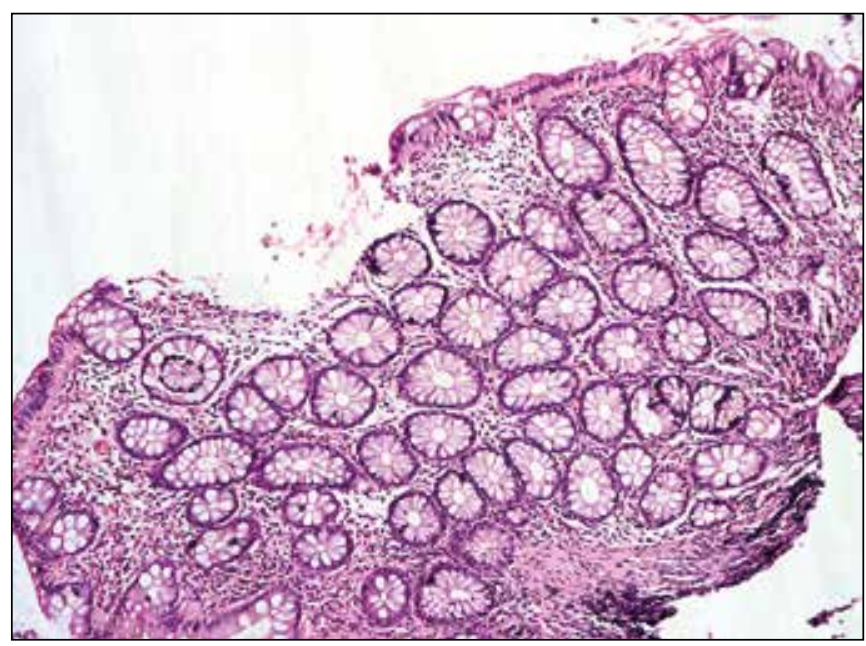

Fig. 1. G 2. Superficial erosive defect in the mucous membrane of the colon. Stained with hematoxylin and eosin, $\times 50$.

transport of nutrients, serves as a substrate for the attachment and nutrition of the commensal microflora, acts as a lubricant, facilitating the passage of the chyme through the intestines [11].

We used the PAS reaction in this research to study morpho-functional features of goblet cells.

In $\mathrm{G} 1$ in all cases when staging the PAS reaction the goblet cells contained a large vacuole with mucin. The nuclei of the goblet cells were small, hyperchromic and basally pushed back. In all cases, mucin had pronounced staining.

In $G 2$, compared with $G 1$, the number of cases with unchanged sizes of vacuoles in goblet cells decreased $(\mathrm{p}<0.05)(22,64.7 \%)$ and cases with focal decrease in the size of vacuoles appeared $(12,35.3 \%)$ (fig. 4$)$. The intensity of mucin staining in this group decreased compared to $G 1$, as evidenced by a decrease $(p<0.05)$ in the number of cases with pronounced staining $(8,23.6 \%)$ and the appearance of cases with weak $(13,38.2 \%)$ and moderate $(13,38.2 \%)$ staining. In the intestinal glands, the intensity of mucin

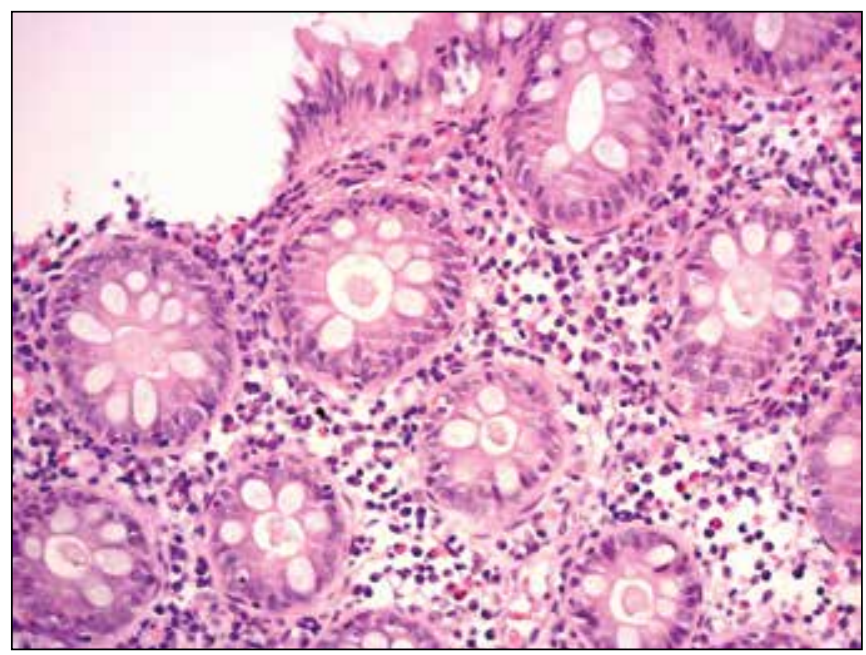

Fig. 3. G5. Moderate inflammatory, dystrophic and desquamative changes in the epithelium of the colon mucosa. Stained with hematoxylin and eosin, $\times 200$.

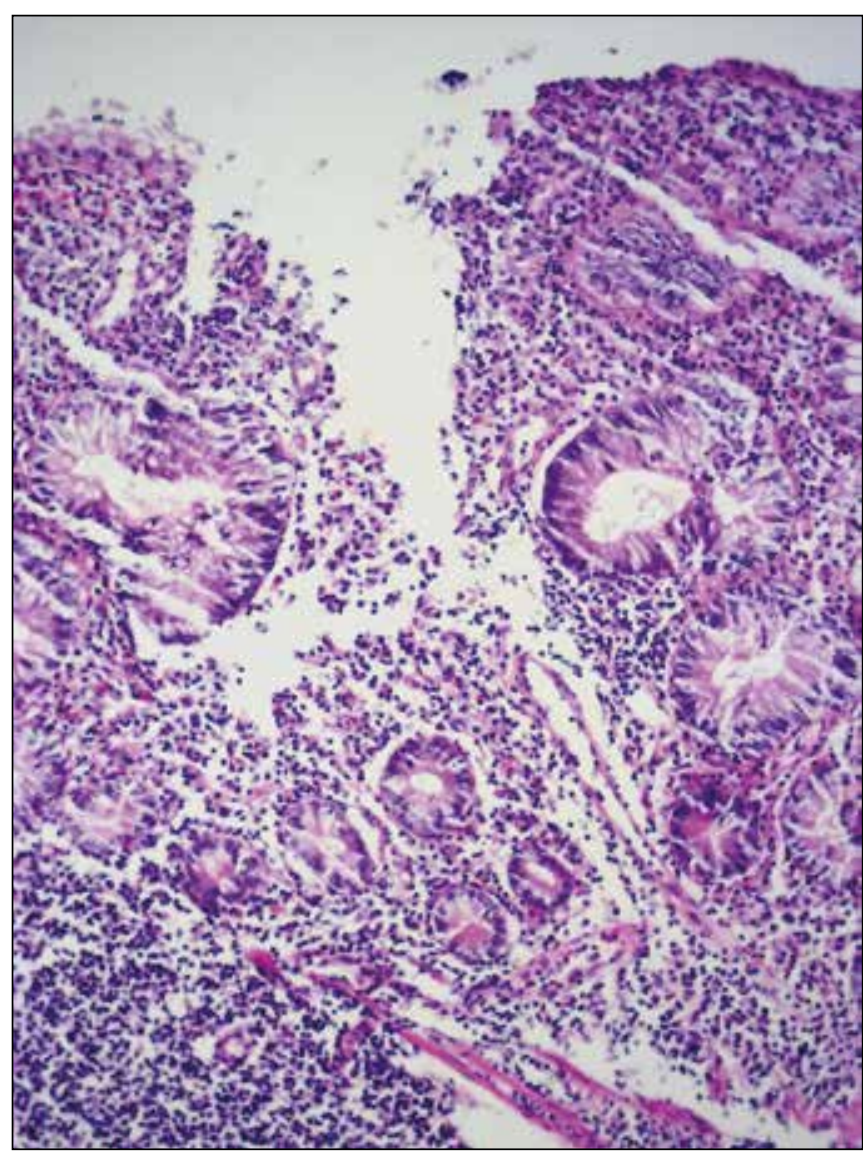

Fig. 2.G 3. Ulcerative defect in the mucous membrane of the colon. Stained with hematoxylin and eosin, $\times 100$.

staining changed in 8 cases $(23.5 \%)$ in their superficial parts, in 12 cases (35.3\%) in $2 / 3$ of their thickness, in 6 cases $(17.7 \%)$ in the entire their thickness.

In the G 3, compared with $G 1$, the number of cases with unchanged in size vacuoles $(9,33.4 \%)$ decreased $(\mathrm{p}<0.05)$, and also there were cases in which vacuoles decreased in size focal $(10,37.0 \%)$ or diffusely $(8,29.6 \%)$.

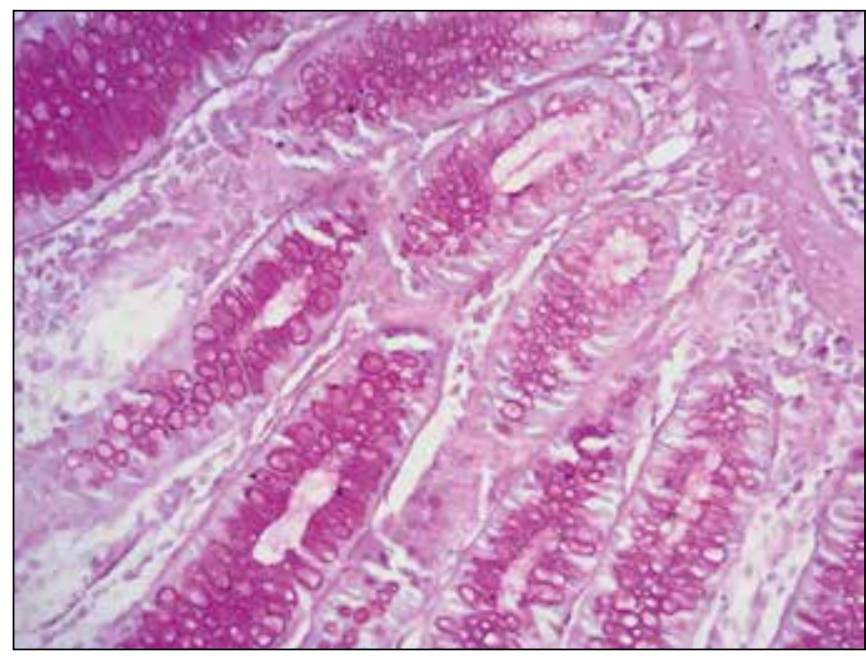

Fig. 4. G 2. Focal decrease in the size of vacuoles with mucin in goblet cells, unevenly pronounced decrease in the intensity of mucin staining. PAS reaction, $\times 200$. 


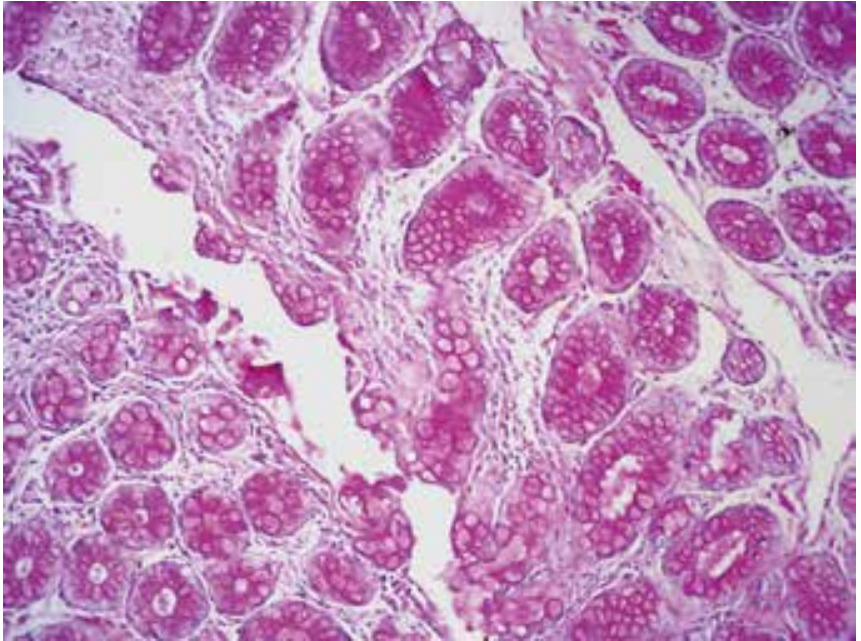

Fig. 5. G 5. Decreased intensity of mucin staining in goblet cell vacuoles. PAS reaction, $\times 100$.

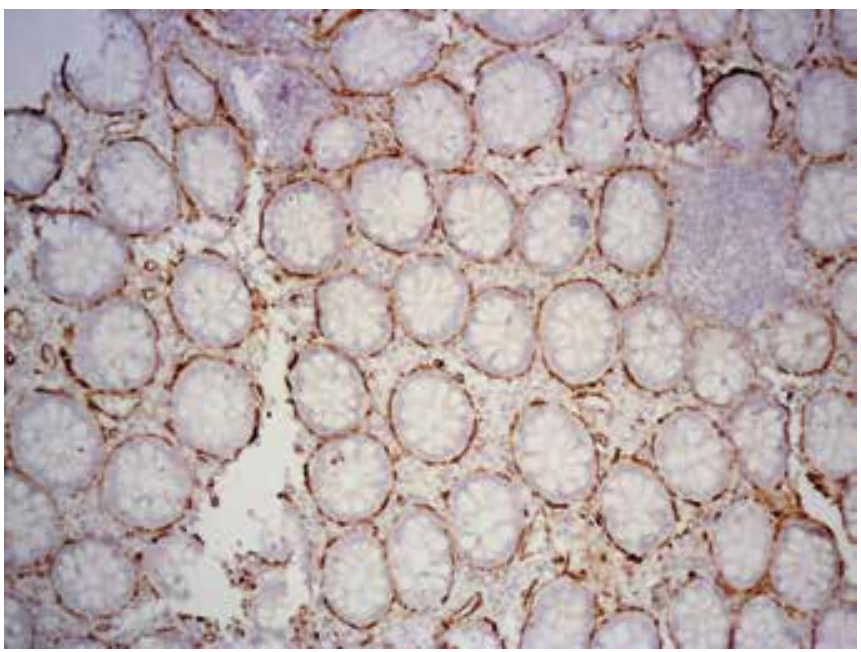

Fig. 7.G5. Evenly spaced pericriptal myofibroblasts. Immunohistochemical reaction with MCA to alpha-smooth muscle actin, $\times 100$.

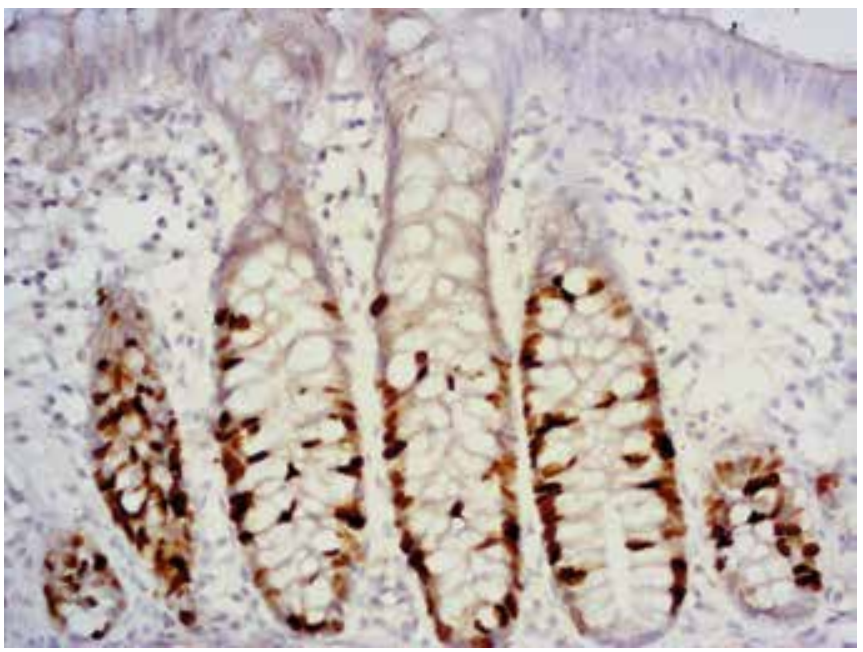

Fig. 9. $G$ 5. Expression of the proliferation marker Ki-67 by the epithelium of the intestinal glands. Immunohistochemical reaction with MCA to $\mathrm{Ki}-67, \times 400$.

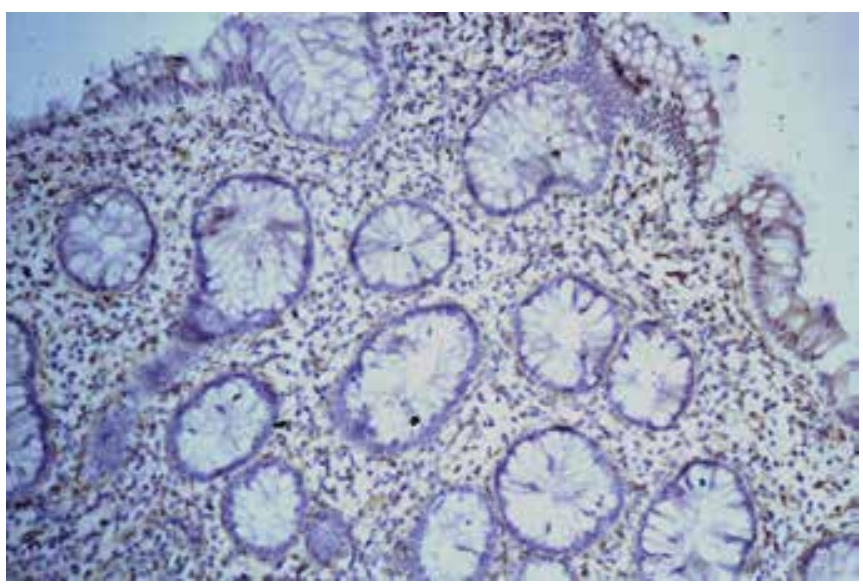

Fig. 6. $G$ 3. Focal or diffuse decrease in the number of pericryptal myofibroblasts. Immunohistochemical reaction with MCA to alpha-smooth muscle actin, $\times 100$.

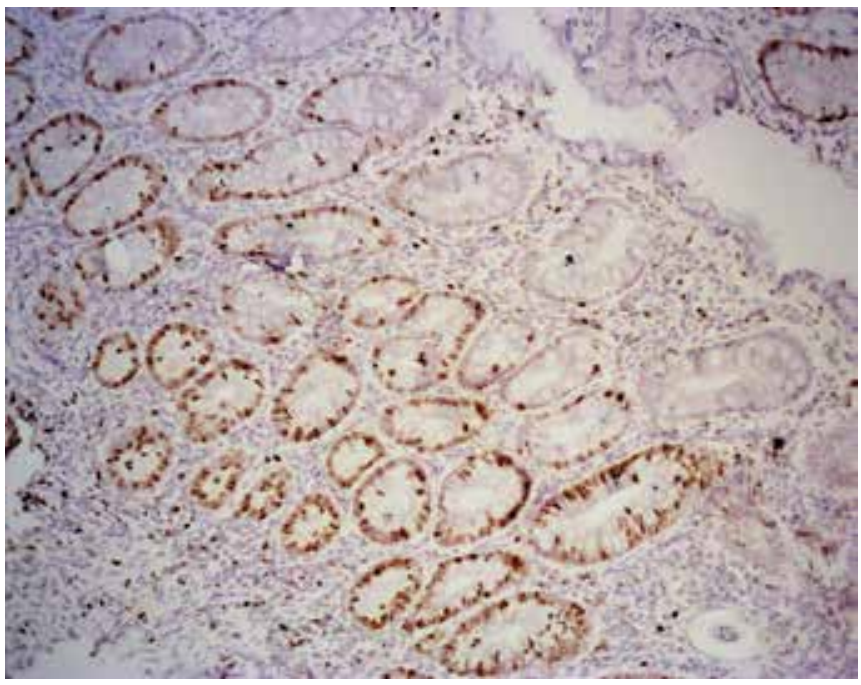

Fig. 8. G3. Expression of the Ki-67 proliferation marker by the epithelium of the intestinal glands. Immunohistochemical reaction with MCA to Ki-67, $\times 100$.

In this group, compared with $\mathrm{G} 1$, the intensity of mucin staining changed (the number of cases with its pronounced staining decreased $(\mathrm{p}<0.05)(7,25.9 \%)$, there were cases with no staining $(2,7.4 \%)$, weak $(14,51.9 \%)$ or moderate $(4,14.8 \%)$ staining). The intensity of mucin staining in 1 case $(3.7 \%)$ changed in the surface parts of the crypts, in 6 cases $(22.2 \%)$ - in their $2 / 3$ of the thickness, in 13 cases $(48.2 \%)$ - in their entire thickness.

In $\mathrm{G} 4$, in $4(21.1 \%)$ and $8(42.1 \%)$ cases, vacuoles of goblet cells of crypts, respectively, focal and diffusely decreased in size, compared with $\mathrm{G} 1$ decreased the number of cases with unchanged sizes of vacuoles $(7,36.8 \%)$. In 4 cases $(21.1 \%)$ a negative PAS reaction was detected, and weak and moderate staining of mucin in $12(63.2 \%)$ and $3(15.7 \%)$ cases. Changing intensity of mucin staining was determined in 1 case (5.3\%) in the superficial parts of the intestinal glands, in 3 cases (15.8\%) - in $2 / 3$ of the thickness of the glands, and in 15 cases $(78.9 \%)$ - in the entire their thickness. 
In $\mathrm{G} 5$ the sizes of goblet cell vacuoles in all cases were similar to $\mathrm{G} 1$. The intensity of mucin staining in this group was weak, moderate and pronounced, respectively, in 15 (18.3\%), $21(25.6 \%)$ and $46(56,1 \%)$ cases (fig. 5). There were fewer cases with a pronounced intensity of mucin staining in this group $(\mathrm{p}<0.05)$, compared with $\mathrm{G} 1$. A change in the intensity of mucin staining in the intestinal glands in 18 cases $(22.0 \%)$ was noted in their superficial parts, in 10 cases $(12.2 \%)$ - in $2 / 3$ of the thickness of the glands, in 8 cases $(9.7 \%)$ - in the entire their thickness.

Summarizing the results of the given PAS reaction, it becomes obvious that a decrease in the size of vacuoles in the goblet cells of crypts, as well as their number, and a decrease in the intensity of mucin staining, contained in the vacuoles of goblet cells, are morphological changes in the mucous membrane of the large intestine characteristic of UC. With an increase in UC activity (from G 2 to G 4), a decrease (focal or diffuse) in the size of vacuoles as well as in the number of goblet cells was noted. The intensity of mucin staining decreased up to its complete disappearance, as evidenced by a negative PAS reaction. It was also noted that there was a decrease in the intensity of mucin staining in UC of the $1^{\text {st }}$ degree of activity, mainly in the superficial parts of the intestinal glands and in their two-thirds of the thickness; UC of the $2^{\text {nd }}$ degree of activity - in $2 / 3$ of the thickness or throughout the entire thickness of crypts, in UC of the $3^{\text {rd }}$ degree of activity - throughout the entire thickness of the crypts.

In our earlier studies, in the works of other scientists, a decreasing number of goblet cells and inhibition of mucus production was also revealed in the mucous membrane of the colon in active UC $[12,13]$.

In IBS, the size of the vacuoles containing mucin in the goblet cells, as well as the number of goblet cells, did not change in the mucous membrane of the colon. The mucin-forming function of the goblet cells suppressed, when staging a PAS reaction, leading to lower intensity of mucin staining, more pronounced in the superficial parts of the intestinal glands.

Thus, in IBS, compared with UC, the number of goblet cells and the size of vacuoles with mucin, containing in these cells, do not change in the mucous membrane of the colon; there is a less pronounced decrease in the intensity of mucin staining.

When setting an immunohistochemical reaction with MCA to alpha-smooth muscle actin in the mucous membrane of the large intestine in G 1, it was revealed evenly spaced pericryptal myofibroblasts. These cells were clear, uniform and had pronounced cytoplasmic brown staining. Myofibroblasts formed a kind of coupling around the intestinal glands. The latter, as we know, provides control over the self-maintenance of crypts [14]. In G 2-4, there was focal or diffuse absence of pericryptal myofibroblasts (fig. 6). In G 5 it was determined features of alpha-smooth muscle actin expression similar to G 1 (fig. 7).

When calculating the relative number of pericryptal myofibroblasts, a decrease $(\mathrm{p}<0.05)$ of this indicator was revealed in G 2-4 (G 2 - (74.4 \pm 2.74$) \%, ~ G 3-(61.6 \pm 2.67) \%$,
G 4 - (50.8 \pm 3.81$) \%)$ compared with G $1((95.3 \pm 2.74) \%)$. From $\mathrm{G} 2$ to $\mathrm{G} 4$, the indicator of the relative number of pericryptal myofibroblasts decreased $(p<0.05)$. In $G 5$, the indicator of the relative number of pericryptal myofibroblasts did not differ significantly $(p>0.05)$ from the control indicator.

Thus, in UC, in contrast to IBS, there is a partial or complete loss of pericryptal myofibroblasts, and the intensity of their expression decreases. With an increase in the degree of UC activity, there is a decrease $(\mathrm{p}<0.05)$ in the number of pericryptal myofibroblasts in the mucous membrane of the large intestine.

The deficiency of pericryptal myofibroblasts leads to the fact that the epithelium in crypts proliferates and grows without their participation. As a result, the architectonics of the crypts disrupts, which is a pathognomonic histological characteristic of the UC. Our survey microscopy revealed a violation of the crypt architectonics in all cases of G 2-4. The severity of this histological finding increased from G 2 to $G$ 4. In G 5, the intestinal glands had histological features similar to $G 1$.

In our study in G 2-4, we found accumulations of myofibroblasts/fibroblasts in the lamina propria or in the muscle lamina of the mucous membrane, as well as in the submucosa against the background of partial or complete disappearance of pericryptal myofibroblasts. Groups of myofibroblasts/fibroblasts often localized at sclerosis loci. As is known, excessive activation of the morpho-functional state of myofibroblasts leads to the overproduction of connective tissue fibers, which contributes to the shortening, thickening of the intestinal wall and, in the future, can lead to disruption of the anatomical structure [15].

An immunohistochemical study with the Ki-67 proliferation marker in all groups revealed its expression by the epithelium of the intestinal glands. In G 1 the expression of this marker was observed mainly in the basal areas of the crypts, with the relative number of Ki-67-positive cells being $(35.6 \pm 0.95) \%$. In G 2-4, the reaction with the proliferation marker increased as compared with $\mathrm{G} 1$. This is evidenced by its predominant expression in $2 / 3$ of the thickness or in the entire crypt thickness (fig. 8), as well as an increase $(\mathrm{p}<0.05)$ in the relative number of Ki-67-positive cells (G $2-(51.9 \pm 0.96) \%$, G $3-(51.2 \pm 1.38) \%$, G 4

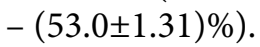

In $G 5$, the expression of the proliferation marker was determined mainly in $2 / 3$ of the thickness of the intestinal glands (fig. 9). The indicator of the relative number of Ki-67-positive cells increased $(p<0.05)$, compared with $G$ 1 and amounted to $(52.7 \pm 0.56) \%$.

It is interesting to note that the expression of the proliferation marker Ki-67 in crypt epithelial cells did not depend on the degree of UC activity and it was not different in IBS and UC of various degrees of activity. Previously identified chronic inflammation in varying degrees of severity in the mucous membrane of the colon in UC and IBS, as well as an increase in the proliferative potential of crypt epithelial cells, from our point of view, can serve as a background for colorectal cancer. The starting point for the realization of 
oncological changes, as we know, are the epithelial cells of the intestinal mucosa $[16,17]$.

At present, there are at least four main pathways of colon cancer carcinogenesis - transformation of adenoma into carcinoma, Lynch syndrome, development of cancer «de novo", transformation of chronic colitis. Carcinogenesis of the «inflammatory» type is as follows: inflammatory changes progress to latent dysplasia, then to mild and severe dysplasia, which transforms into cancer [18].

Equally pronounced features of crypt epithelium proliferative activity in UC and IBS, identified by author, should develop oncological alertness both in doctors and in patients. The authors of Rome IV Criteria recommend colonoscopy for patients with IBS over 50 years of age with "anxiety symptoms» and a family history of colorectal cancer [19]. Our results indicate the need to revise the above recommendations for colonoscopy in patients with IBS.

\section{CONCLUSIONS}

1.There are characteristic morphological changes in the mucous membrane of the large intestine in UC of varying degrees of activity, such as changes in the architectonics of crypts of varying severity; presence of erosive and ulcerative defects. Inflammatory and desquamative-dystrophic changes take place in the epithelial layer adjacent to erosive and ulcerative defects. The number of goblet cells of crypts decreases and the size of vacuoles in goblet cells reduces. The intensity of mucin secretion contained in the vacuoles of the goblet cells lowers; there is a partial or complete loss of pericryptal myofibroblasts; the proliferative potential of the intestinal crypts epithelium activates.

2. Severity of erosive-ulcerative changes in epithelium increases with rising UC activity; changes in the architectonics of crypts become more noticeable. Inflammation and desquamative-dystrophic changes in the epithelial layer intensifies. The number of goblet cells and the size of vacuoles in these cells decrease. The intensity of mucin staining in the vacuoles of the goblet cells decreases until its complete disappearance as well as the number of pericryptal myofibroblasts, while the proliferative activity of the crypt epithelium remains unchanged.

3. In IBS, there are inflammatory and dystrophic changes in the epithelium in the mucous membrane of the colon, sometimes combined with desquamative changes; the intensity of mucin staining in the goblet cell vacuoles decreases; the proliferative potential of crypt epithelial cells grows.

4. In the mucous membrane of the large intestine in IBS, compared with UC, the architectonics of crypts is not disturbed, erosive and ulcerative changes are not determined. Less pronounced inflammatory and dystrophic changes in the epithelium sometimes combine with desquamative changes. The number of goblet cells and the size of the vacuoles with mucin that contain these cells do not change. There is a less pronounced decrease in the intensity of mucin staining; the number of peric- ryptal myofibroblasts corresponds to the physiological norm. The proliferative activity of crypt epithelium does not differ in IBS and UC of varying degrees of activity.

5. In the mucous membrane of the large intestine in UC of varying degrees of activity and IBS, it was established an activation of the proliferative potential of the epithelial cells of the intestinal glands, which should generate equally pronounced oncological alertness in doctors and patients. The revealed features of the proliferative activity of the crypt epithelium in patients with IBS actualize the need to revise the recommendations of the Rome IV criteria regarding colonoscopy in these patients.

6. Differential diagnostic criteria, revealed by the author, improve the morphological diagnosis of UC and IBS, optimizing the tactics of managing patients with this colorectal pathology.

\section{REFERENCES}

1. Stepanov YuM, Skirda IYu, Petishko OP. Hvoroby organiv travlennja - aktualna problema klinichnoi medycyny. Digestive system diseases: the actual problem of clinical medicine. Gastroenterologia. 2019;53(1):1-6. (Ua)

2. Ivashkin VT, Shelygin YuA, Abdulganiyeva DI, Abdulkhakov RA, Alekseyeva OP, Achkasov SI et al. Rekomendacii Rossijskoj gastrojenterologicheskoj associacii i Associacii koloproktologov Rossii po diagnostike i lecheniju vzroslyh bolnyh jazvennym kolitom. Guidelines of the Russian gastroenterological association and Russian Association of Coloproctology on diagnostics and treatment of ulcerative colitis in adult. Russian Journal of Gastroenterology, Hepatology, Coloproctology. 2015;1:48-65. (Ru)

3. Rastogi A, Wani S. Colonoscopy. Gastrointestinal endoscopy. 2017;85(1):59-66.

4. Ivanova EV, Fedorov ED, Tikhomirova EV, Avakimyan AV, Marenich NS. Kolonoskopija s pomoshhju videokapsuly: vozmozhnosti neinvazivnoj diagnostiki zabolevanij tolstoj kishki. Colon capsule endoscopy: possibilities of non-invasive diagnostics of colon diseases. Research'n Practical Medicine Journal. 2017;4(1):13-22. (Ru)

5. Feakins RM. Inflammatory bowel disease biopsies: updated British Society of Gastroenterology reporting guidelines. Journal of Clinical Pathology. 2013; 66(12):1005-1026.

6. Geboes K, Nemolato S, Leo M, Faa G, eds. Colitis. A practical approach to colon biopsy interpretation. Springer, $2014.200 \mathrm{p}$.

7. Sheptulin AA, Vinogradskaya KE.Vospalitelnye zabolevanija kishechnikai sindrom razdrazhennogo kishechnika: sochetanie dvuh nozologicheskih form ili raznye varianty odnogo zabolevanija? Inflammatory bowel diseases and irritable bowel syndrome: overlap of two nosological forms or two variants of the same disease? Russian Journal of Gastroenterology, Hepatology, Coloproctology. 2019;29(5):43-48. (Ru)

8. Kobzar Al. Prikladnaja matematicheskaja statistika. Applied mathematical statistics. M.: Fizmatlit, 2012.816 p. (Ru)

9. DeRoche TC, Xiao S-Y, Liu X. Histological evaluation in ulcerative colitis. Gastroenterology Report. 2014;2:178-192.

10. Osadchuk AM, Ivashkin VT. Diffuznaja jendokrinnaja sistema i narushenie processov kletochnogo obnovlenija kolonocitov pri razlichnyh stepenjah tjazhesti nespecificheskogo jazvennogo kolita. Diffuse endocrine system and disorders of cellular regeneration of colonocytes in nonspecific ulcerative colitis. Vestnik of Volgograd State Medical University. 2005;3(15):58-61. (Ru) 
11. Zolotova NA, Akhrieva KhM, Zayratyants OV. Jepitelialnyj barer tolstoj kishki v norme i pri jazvennom kolite. Epithelial barrier of the colon in health and patients with ulcerative colitis. Clinical Gastroenterology.2019;162(2):4-13. (Ru).

12. Snisarevskyi PP, Dyadyk 00, Dorofeyev AE, Snisarevska PP. Rol morfologichnogo doslidzhennja v diagnostyci nespecyfichnogo vyrazkovogo kolitu. The significance of morphological research in the diagnosis of ulcerative colitis. Art of medicine. 2018;3(7):127-132. (Ua)

13. Stange EF, Schroeder BO. Microbiota and mucosal defense in IBD: an update. Expert Review of Gastroenterology and Hepatology. 2019;13(10):963-976.

14. Barinov EF, Sulayeva ON. Gastrointestinalnye miofibroblasty - rol v reguljacii fiziologicheskoj aktivnosti ireparaciizheludochno-kishechnogo trakta. Gastrointestinal myofibroblasts: role in regulation of physiological activity and reparation of gastro-intestinal tract. Russian Journal of Gastroenterology, Hepatology, Coloproctology. 2010;3:9-18.(Ru)

15. Fedulova EN, Zhukova EA, Tutina OA, Kuznetsova TA, Shumilova OV, Fedorova OV. Nekotorye morfologicheskie kriterii prognozirovanija stepeni tjazhesti techenija bolezni Krona u detej. Morphological criteria for prediction of severity of Crohn's disease clinical course in children. Current Pediatrics. 2013;12(5):108-111. (Ru)

16. Nikipelova EA, Kit OI, Shaposhnikov AV, Zlatnik EY, Novikova IA. Kolokancerogenez: onkoimmunologija lokalnyh izmenenij. Colocarcinogenesis: oncoimmunology of local changes. Malignant tumours. 2016;4(1):81-86. (Ru)

17. Tamm TI, TsodikovVV, SedakVV, Pliten ON, Miroshnichenko MS. Izmenenie gistostruktury hronicheskoj analnoj treshhiny v zavisimosti ot dlitelnosti zabolevanija. Changes of histostructure of chronic anal fissure, depending on duration of the disease. Klinichna khirurhiia. 2016;(1):54-57. (Ru)
18. Raskin GA, Petrov SV, Orlova RV. Osobennosti kancerogeneza adenokarcinomy tolstoj kishki. Special features of carcinogenesis of colon adenocarcinoma. Siberian Journal of Oncology. 2015;4:73-79. (Ru)

19. Schmulson MJ, Drossman DA. What is new in Rome IV. Journal of Neurogastroenterology and Motility. 2017;23(2):151-163.

\section{ORCID and contributionship:}

Pavlo P. Snisarevskyi: 0000-0002-4454-3678

\section{Conflict of interest:}

The Author declare no conflict of interest

\section{CORRESPONDING AUTHOR Pavlo P. Snisarevskyi}

Pathological and Topographic Anatomy Department, Shupyk National Healthcare University of Ukraine 9 Dorohozhytska str. Dnipro, 04112, Ukraine e-mail: patholognew@ukr.net

Received: 10.11 .2020

Accepted: 24.02 .2021

A - Work concept and design, B - Data collection and analysis, C - Responsibility for statistical analysis, D-Writing the article, $\mathbf{E}$-Critical review, $\mathbf{F}$ - Final approval of the article 